\title{
Ploidy Levels, Relative Genome Sizes, and Base Pair Composition in Cotoneaster
}

\author{
Joseph J. Rothleutner \\ Lincoln Park Zoo, 2001 North Clark Street, Chicago, IL 60614 \\ Mara W. Friddle and Ryan N. Contreras ${ }^{1}$ \\ Department of Horticulture, Oregon State University, 4017 Agricultural and Life Sciences Building, \\ Corvallis, OR 97331
}

\begin{abstract}
AdDitional INDEX wORDs. Rosaceae, Maloideae, chromosome number, flow cytometry
Abstract. The genus Cotoneaster (Rosaceae, Maloideae) is highly diverse, containing $\approx 400$ species. Like other maloids, there is a high frequency of naturally occurring polyploids within the genus, with most species being tetraploid or triploid. Apomixis is also prevalent and is associated with polyploidy. The objective of this study was to estimate genome sizes and infer ploidy levels for species that had not previously been investigated as well as compare estimates using two fluorochromes and determine base pair (bp) composition. Chromosome counts of seven species confirmed ploidy levels estimated from flow cytometric analysis of nuclei stained with $4^{\prime}$,6-diamidino-2-phenylindole (DAPI). Monoploid (1Cx) genome sizes ranged from 0.71 to $0.96 \mathrm{pg}$. Differences in monoploid genome size were not related to current taxonomic treatment, indicating that while chromosome sizes may vary among species, there are no clear differences related to subgeneric groups. A comparison of DAPI and propidium iodide (PI) showed a difference in DNA staining in Cotoneaster comparable to other rosaceous species. Base pair composition (AT\%) in Cotoneaster ranged from $58.4 \%$ to $\mathbf{6 0 . 8 \%}$, which led to overestimation of genome size estimates in many cases-assuming the estimates of the DNA intercalator are accurate. Our findings will inform breeders with regard to the reproductive behavior of potential parents and may be used to confirm hybrids from interploid crosses.
\end{abstract}

Cotoneaster is a genus of woody plants composed of $\approx 400$ species that range in habit from tight, impenetrable groundcovers to airy shrubs and medium-sized trees. The center of species diversity is the Himalayas and mountains of Yunnan and Sichuan provinces of China. The distribution encompasses the temperate zones of Eurasia and Northern Africa. The northern end of the range stretches from Spain to Siberia, and the southern limit extends from Morocco to the southern tip of India and South Korea (Fryer and Hylmö, 2009).

Although there are hundreds of species of Cotoneaster, a relatively small percentage are commonly grown in ornamental landscapes, as illustrated by Dirr (2009) listing only 14. These species were selected for their multiseason interest from flowers, fruit, and plant habit. In the 2014 Census of Horticultural Specialties (U.S. Department of Agriculture, 2014), Cotoneaster sales were estimated to exceed $\$ 7$ million in the United States, although the value is likely greater because this figure accounted only for sales of Cotoneasters classified as "broadleaf evergreens" and many species are deciduous or semievergreen depending on climate and environmental factors.

Cotoneaster is a member of Rosaceae, subfamily Maloideae, and appears to be most closely related to Pyracantha (firethorn) and Heteromeles (christmas berry) (Robertson et al., 1991;

Received for publication 30 Mar. 2016. Accepted for publication 7 June 2016. This study is from a thesis submitted by Joseph. J. Rothleutner as partial fulfillment of the degree of master of science in Horticulture at Oregon State University.

This research was funded, in part, by the Oregon Agricultural Experiment Station and by USDA-ARS Specific Cooperative Agreement 58-1230-3-501.

We are grateful for germination and early maintenance of plants by Imogene Hollis and Heather Stoven. Also, we extend our gratitude to contributing gardens and nurseries for generously supplying plants or seeds.

${ }^{1}$ Corresponding author. E-mail: ryan.contreras@oregonstate.edu.
Rohrer et al., 1992). Taxonomy at the family level is complicated, with interspecific and intergeneric hybridization being common. Interspecific hybrids of several species of Cotoneaster have been reported, and Cotoneaster melanocarpus has reportedly hybridized with Sorbus acuparia ssp. siberica to form the intergeneric hybrid $\times$ Sorbocotoneaster (Fryer and Hylmö, 2009). Within Cotoneaster, there are two subgenera, Chaenopetalum and Cotoneaster, which are primarily defined by floral morphology. These subgenera have been further divided into 11 sections based on botanical characteristics, and further dissected into 37 series based on botanical characteristics and geographic origins of the species (Flinck and Hylmö, 1966). However, keys associated with this treatment are ambiguous and often of limited use for species identification. We are collaborating with Hoyt Arboretum (Portland, OR) to identify and evaluate our germplasm collection, with little success in identifying unknown samples.

The base chromosome number of Maloideae is 17 and is thought to be of allopolyploid origin - perhaps derived from a hybridization event between other subfamilies in Rosaceae [Rosoideae $(x=7,8,9)$, Spiraeoideae $(x=9)$, Amygaloideae $(x=8)$ ] followed by a whole genome doubling event (Dickson et al., 1992; Sax, 1954). Cotoneaster species show a ploidy series, with estimates of $70 \%$ tetraploid $(2 n=4 x=68), 15 \%$ triploid $(2 n=3 x=51)$, and $10 \%$ diploid $(2 n=2 x=34)$, and the remaining species of greater ploidy level (Fryer and Hylmö, 2009). Apomixis is common in Cotoneaster and appears to be associated with polyploidy, as the tetraploids and triploids are frequently obligate or rarely facultative apomicts, while diploid progeny are sexually derived (Bartish et al., 2001; Czapik, 1996; Hjelmqvist, 1962; Nybom and Bartish, 2007).

Because apomixis is so common in polyploid Cotoneaster, knowledge of ploidy level is essential for breeders to design 
crosses with hopes of hybrid seed, as the female must be a sexually fertile diploid. In addition, information on ploidy level, genome size, and bp composition may give taxonomists and phylogeneticists insight to the evolution and organization of the genus and related taxa. Previous reports of genome sizes in Cotoneaster are limited; therefore, our goals were to determine relative genome sizes and produce ploidy estimates across a wide selection of Cotoneaster including its breadth of taxonomic groups.

\section{Materials and Methods}

Plant material. Germplasm was collected through various means including whole plants from nurseries, cuttings from gardens and arboreta, and seeds from gardens around the world participating in Index Seminum (Table 1). The latter formed the bulk of our collection. Plants were maintained in containers or in field plots at Oregon State University and all were assigned accession numbers.

Genome sizing. Holoploid (2C) genome sizes were determined by flow cytometry (CyFlow PA; Partec, Münster, Germany) and comparison of mean relative fluorescence of the sample against an internal standard, Pisum sativum 'Ctirad', with a known genome size of 8.76 pg (Greilhuber et al., 2007). Two different fluorochromes were used. A total of 67 accessions representing 65 species were sampled across the two subgenera and all 11 sections using flow cytometric analysis of nuclei stained with DAPI (CyStain ultraviolet Precise P; Partec). A subset of 17 taxa was also prepared with PI (CyStain ultraviolet Absolute P; Partec). Nuclei of each sample and our standard were concurrently prepared by chopping with a double-sided razor blade in extraction buffer (CyStain ultraviolet Precise P Nuclei Extraction Buffer; Partec) for $\approx 90 \mathrm{~s}$ before being filtered through a $50-\mu \mathrm{m}$ nylon mesh filter (CellTrics ${ }^{\circledR}$; Partec) and stained with either fluorochrome. For PI-stained samples, RNase was included to ensure staining of DNA exclusively. Cotoneaster samples were prepared using 4 $\mathrm{cm}$ of rapidly growing terminal stem tissue including vegetative buds and we used $1 \mathrm{~cm}^{2}$ of fresh pea leaf tissue. DAPI-stained samples were incubated in darkness for 5 to $10 \mathrm{~min}$ before analysis and PI-stained samples were incubated in darkness for at least $30 \mathrm{~min}$ on ice. Three replicates of each accession were prepared for both DAPI and PI. A minimum of 3000 particles were analyzed for each sample. Sample runs were rejected if the coefficient of variation (CV) was greater than $7 \%$.

Holoploid DNA content (2C) was calculated as DNA content of standard $\times$ (mean fluorescence value of sample/ mean fluorescence of standard). Then, analysis of variance and means separation by Tukey's honestly significant difference was performed, with ploidy levels inferred from mean separation. Monoploid genome sizes were calculated by dividing each sample's 2C genome size by inferred ploidy. Analysis of variance was then conducted on monoploid genome size by accession and then taxonomic division to test for significant differences among subgenera or sections; mean separation was performed as described above when the model was significant $(\alpha=0.05)$. For the subset of 17 accessions that were examined with both DAPI and PI, genome size estimates using each fluorochrome were compared using a $t$ test $(\alpha=0.05)$ separately for each accession. Base pair composition was calculated as $\mathrm{AT} \%=\mathrm{AT} \%$ for internal standard $\times\{[$ (fluorescence sample, DAPI)/(fluorescence internal standard, PI/fluorescence sample, $\left.\mathrm{PI})]^{(1 / \text { binding length) }}\right\}$ (Godelle et al., 1993). AT\% of $P$. sativum
'Ctirad' is $61.50 \%$ and has a binding length of $\approx 3.5 \mathrm{bp}$ (Meister and Barrow, 2007).

Cytology. Chromosomes were counted for seven species, five of which were included in the genome sizing, and two additional species Cotoneaster hebephyllus and Cotoneaster poluninii. Somatic cells were collected from actively growing root tips, which grew freely from the bottom of their containers into sand. Roots were treated with 0.003 м 8-hydroxyquinoline for $2 \mathrm{~h}$ at $4{ }^{\circ} \mathrm{C}$ and fixed in Carnoy's solution [ 6 absolute ethanol : 3 chloroform : 1 glacial acetic acid (by volume)] overnight. Root tips were stored in $70 \%$ ethanol at $4{ }^{\circ} \mathrm{C}$ until prepared for chromosome counts (Goldblatt and Gentry, 1979). Chromosomes were examined by root tip squashes with modified carbol fuchsin, at $\times 63$ to $\times 100$ magnification (Axio imager.A1; Zeiss, Thornwood, NY) and images were collected using a monochromatic CCD camera (AxioCam MRm; Zeiss). A minimum of three cells were counted for each species.

\section{Results and Discussion}

Relative 2C genome sizes for 67 accessions determined by flow cytometry with DAPI ranged from $1.52 \mathrm{pg}$ (Cotoneaster frigidus) to $4.71 \mathrm{pg}$ (Cotoneaster kweitschoviensis) (Table 2). The $2 \mathrm{C}$ genome sizes showed marked divisions, which were used to assign ploidy level. Of the 67 accessions, 10 (15\%) were diploids $(2 n=2 x=34)$ with $2 \mathrm{C}$ values ranging from 1.52 to 1.73 pg, $5(9 \%)$ were triploids $(2 n=3 x=51)$ with $2 \mathrm{C}$ values ranging from 2.14 to $2.58 \mathrm{pg}, 51(76 \%)$ were tetraploids $(2 n=4 x=68)$ with $2 \mathrm{C}$ values ranging from 2.88 to $3.34 \mathrm{pg}$, and $1(1.5 \%)$ accession was hexaploid $(2 n=6 x=102)$ with a $2 \mathrm{C}$ value of 4.71 pg (Table 2). Regarding relative percentage of ploidy levels, our findings generally agree with previous reports including Kroon (1975) who reported 3 diploid, 3 triploid, and 23 tetraploid species among the 28 studied. Ours is the first report of ploidy estimation for 13 of the species. However, one diploid species, Cotoneaster juratana, is not a valid species and we have been unable to confirm its identity. One assumption was a mislabeling of Cotoneaster juranus, which has only been reported as a tetraploid (Fryer and Hylmö, 2009). Unfortunately, morphology of the plant labeled as $C$. juratana did not match the description of $C$. juranus and has since been lost from our collection. We sampled two accessions of Cotoneaster adpressus and Cotoneaster acutifolius and both showed ploidy series. Cotoneaster adpressus 10-0157 was tetraploid and the other, 'Tom Thumb', was triploid. Previous reports for $C$. adpressus indicated that it was either diploid or triploid (Sax, 1954; Zeilinga, 1964), making ours the first report of tetraploidy for the species. Cotoneaseter acutifolius 09-0047 was diploid and C. acutifolius 10-0126 was triploid. Our results are consistent with Sax (1954) who reported diploids, triploids, and tetraploids for C. acutifolius. This is in contrast to Zeilinga (1964) who reported that all species in their study were diploid or tetraploid and only cultivars were found to be triploid. This provides evidence that 'Tom Thumb' and C. acutifolius 100126 are hybrids. Cotoneaster $\times$ watereri $10-106$ was a triploid in contrast to previous reports indicating this hybrid species to be diploid (Fryer and Hylmö, 2009). This species arose as a hybrid of $C$. frigidus $\times$ Cotoneaster salicifolius, which generally are both regarded as diploids, though Sax (1954) also reported triploidy in $C$. salicifolius. It is unclear how this triploid accession arose, but possibilities include a previously unknown tetraploid cytotype of one of the parent species, 


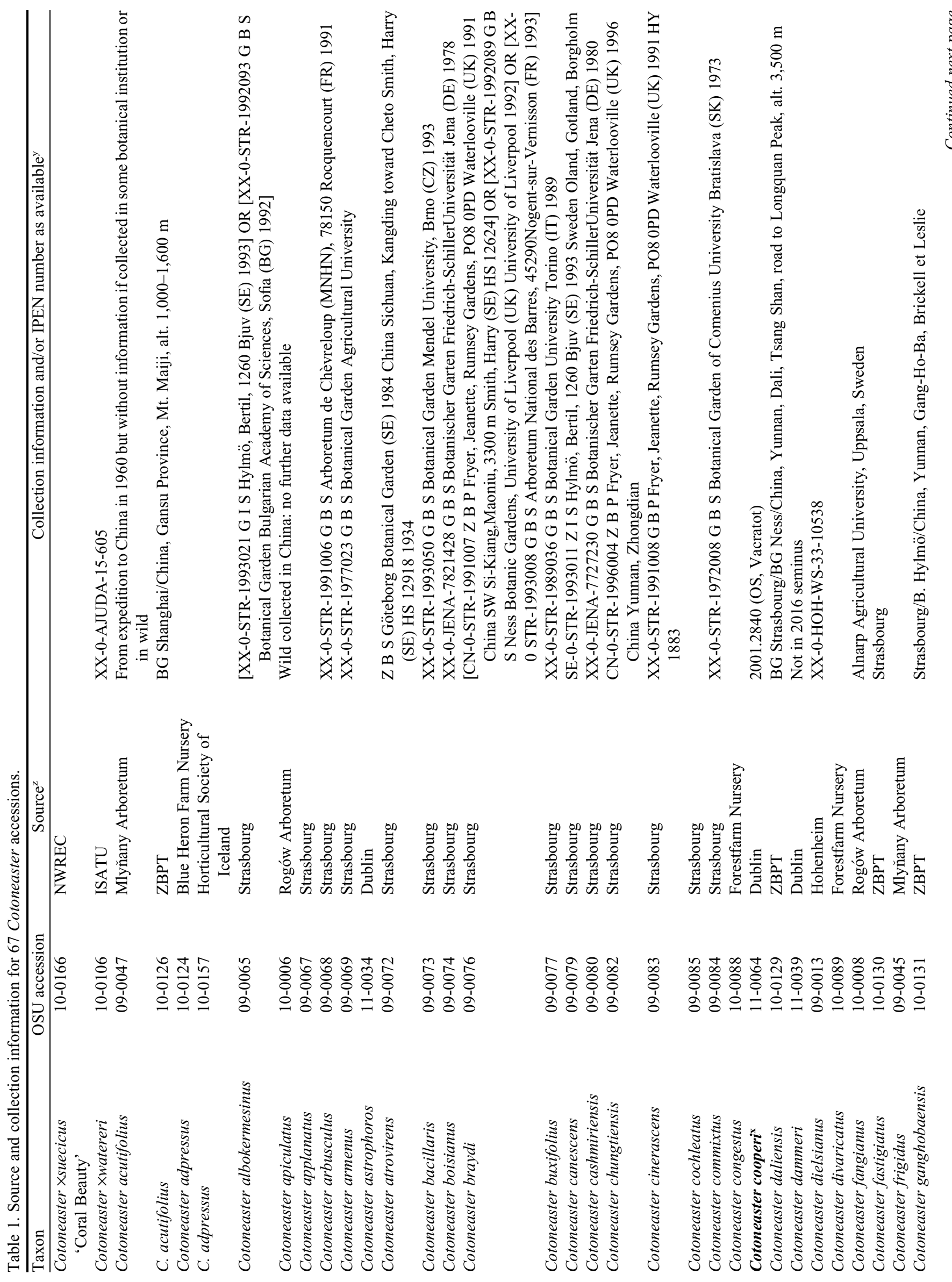




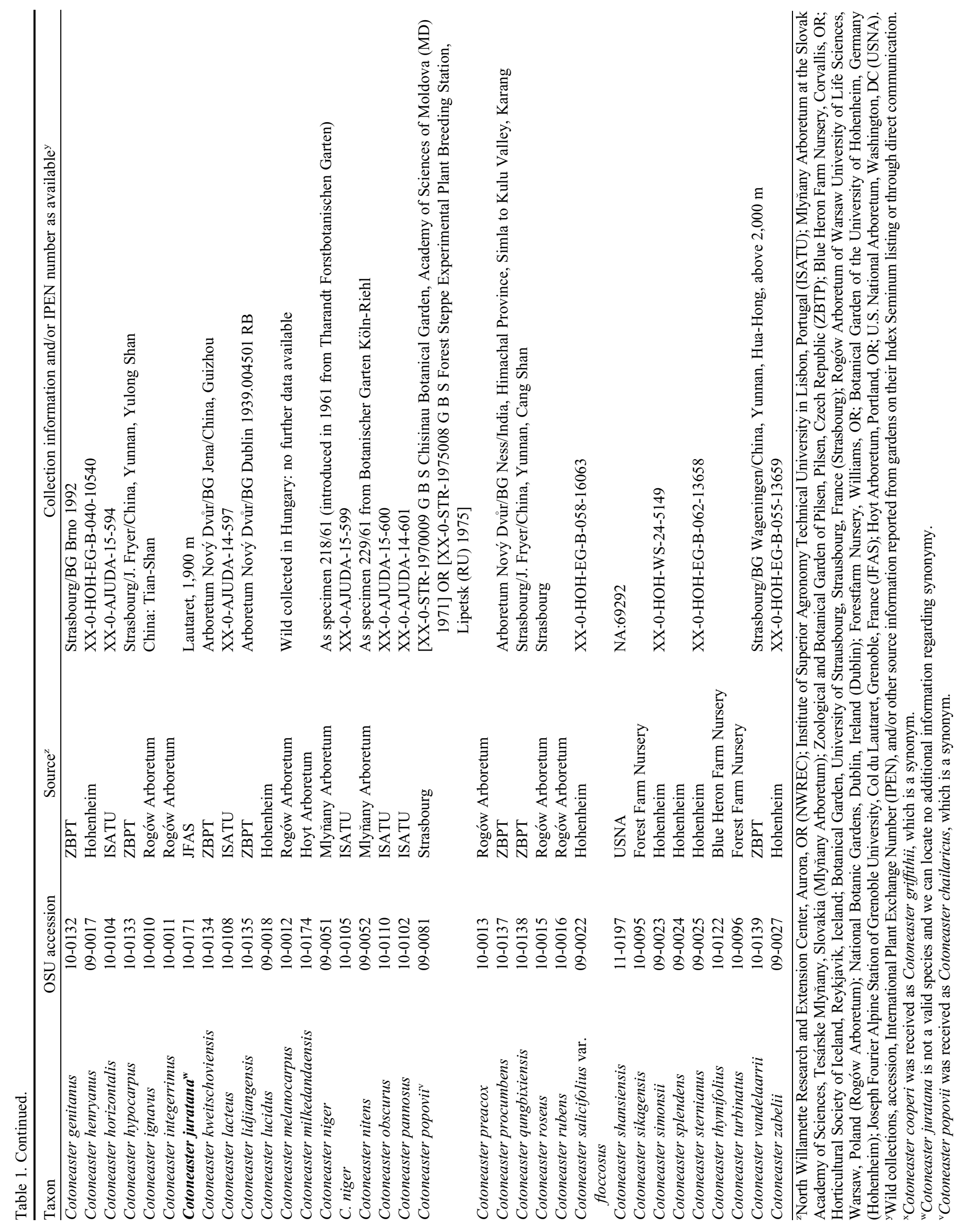




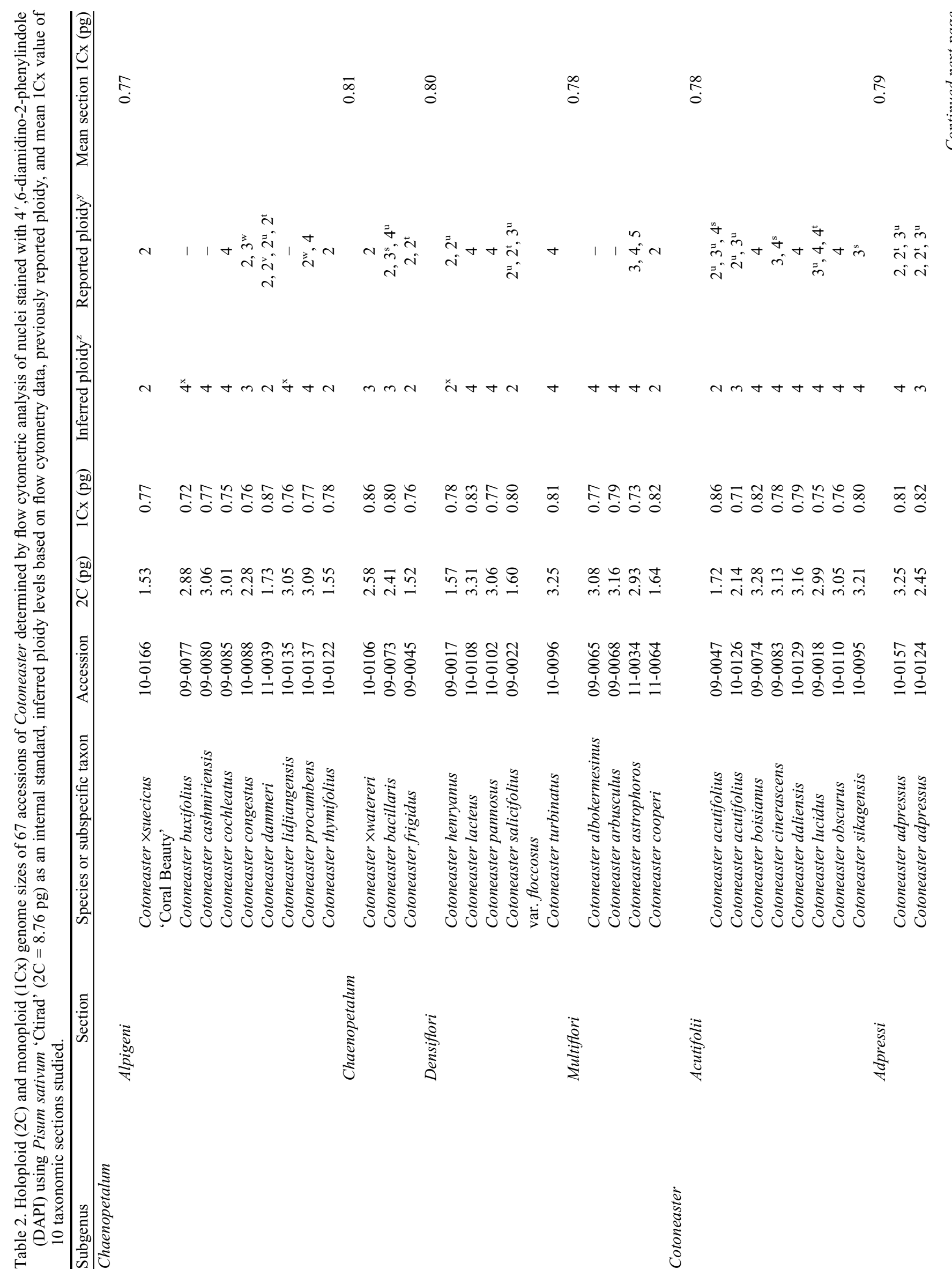




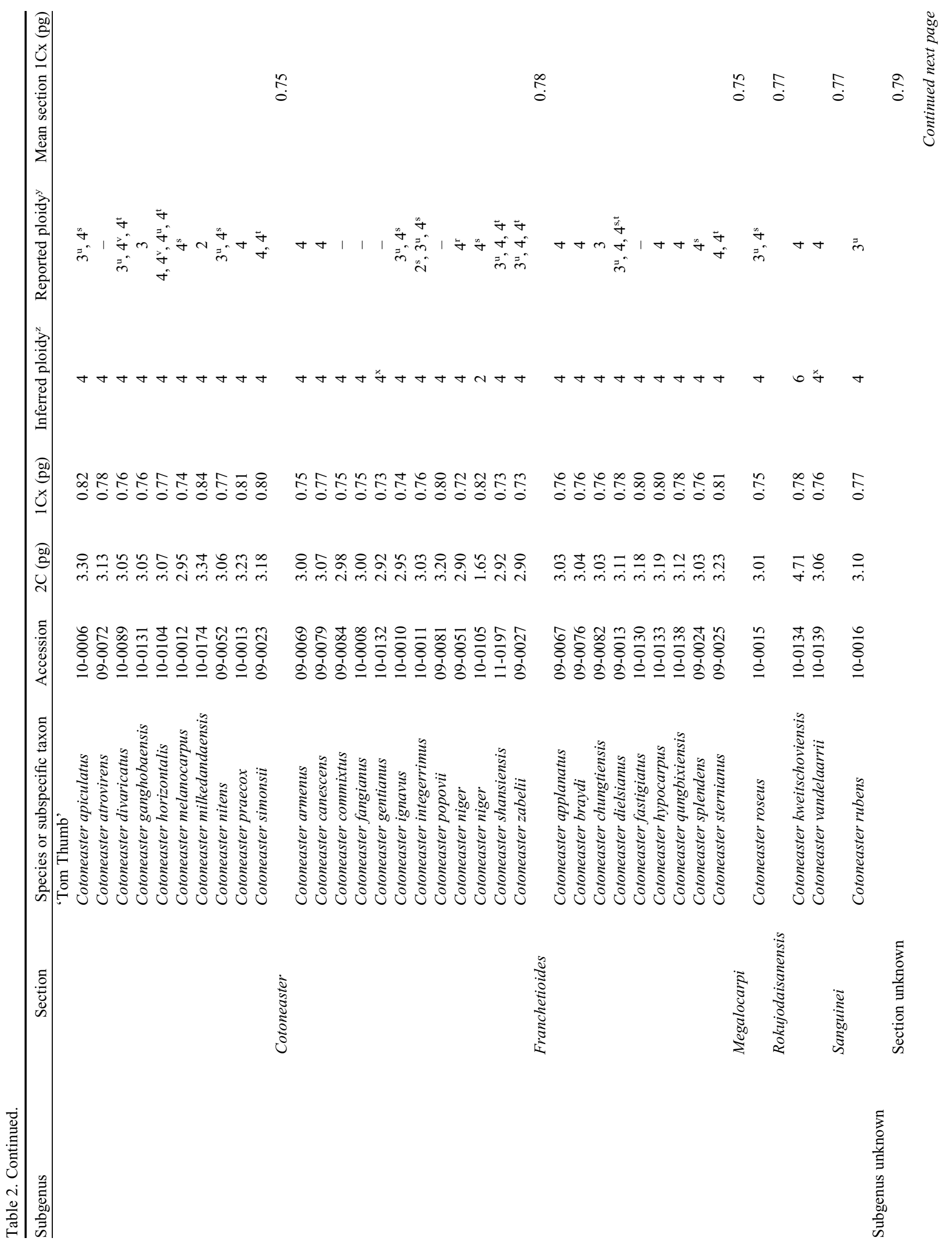




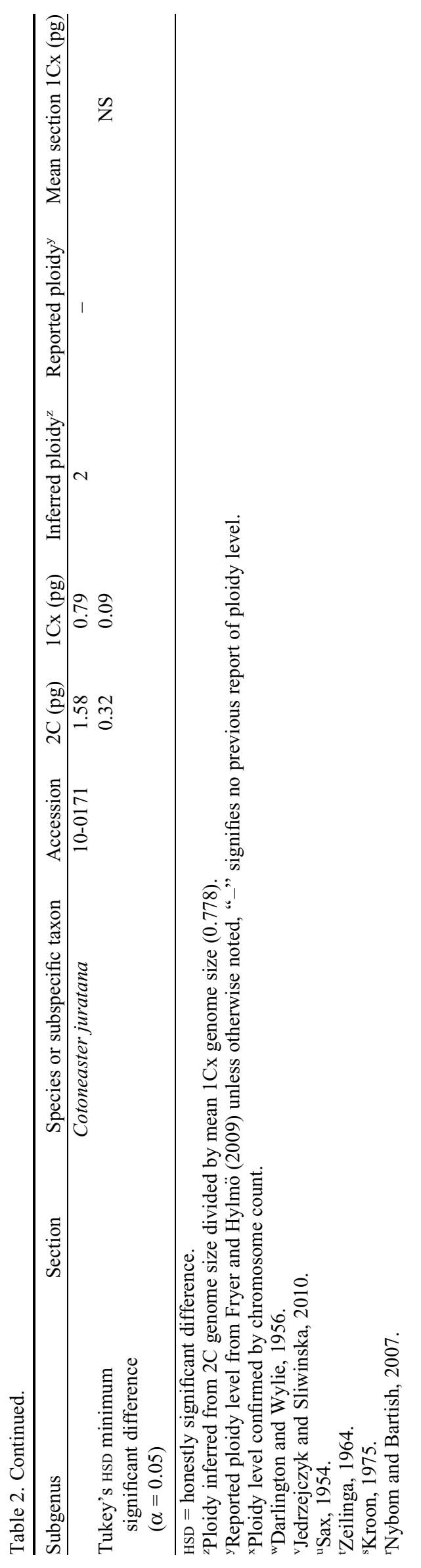

unreduced gamete production in one of the progenitors, an apomictic seedling, or even a self-pollinated seedling from an unreported triploid cytotype of $C$. salicifolius, as triploids often are regarded as facultative apomicts. Another alternative is that the parent plant from which we received seed was diploid and it was accidentally pollinated by a tetraploid, resulting in triploid progeny. There is some evidence against obligate apomixis in C. Xwatereri, as Fryer and Hylmö (2009) describe five cultivars, a level of diversity that would not be expected if the species was an obligate apomict. Both Zeilinga (1964) and Kroon (1975) reported that all species were diploid or tetraploid and triploids only arise through hybridization. To determine if that assertion is supported by our study, a detailed morphological or molecular investigation of species and hybrids would be required, which is beyond the scope of the current research. In five other species, our data indicated a different cytotype than reported by Fryer and Hylmö (2009). These include Cotoneaster ganghobaensis, C. kweitschoviensis, Cotoneaster milkedandaensis, Cotoneaster niger, and Cotoneaster sikagensis. The differing cytotypes we report do not suggest consistent error in either direction (over or underestimates) and include two $4 x$ that were reportedly $3 x$, one $6 x$ previously reported as $4 x$, one $4 x$ previously reported as $2 x$, and one $2 x$ previously reported as $4 x$ (Table 2). A larger screening with more accessions representing each species would likely uncover more ploidy series within other species as well as identifying more examples for which new findings would differ from previous reports. Discrepancies in ploidy between previous papers and our findings are due to testing different sources or accessions of material, some of which may have arisen from hybridization.

When looking across taxonomic divisions, variation in ploidy level was observed in the subgenera and within many sections (Table 2). The $1 \mathrm{Cx}$ genome size ranged from $0.71 \mathrm{pg}$ of DNA for C. acutifolius (10-0126) to $0.87 \mathrm{pg}$ of DNA for Cotoneaster dammeri. When compared across all taxa, monoploid genome sizes showed a detectable difference $(P<0.05)$; however, when these differences were examined by taxonomic division, they were insignificant $(P \geq 0.05)$. Since we did not observe differences between taxonomic groups, we infer that our mean monoploid genome size can be used to calibrate our ploidy estimations in future investigations. In addition, when compared with other genera like Magnolia, which has observable differences in monoploid genome size between taxonomic sections (Parris et al., 2010), Cotoneaster has undergone relatively little divergence in chromosome size.

DAPI genome size estimates generally were larger than PI with differences ranging from 0.03 to $0.14 \mathrm{pg}$ (Table 3 ). Fifteen of 17 accessions were different $(P<0.05)$ using respective fluorochromes and four accessions had higher significance $(P<$ $0.0001)$. Doležel et al. (1992) reported significant differences $(P<0.01)$ for five genera in four families including four genera for which DAPI overestimated genome size from $11 \%$ to $30 \%$ compared with PI and one species for which DAPI underestimated genome size by nearly $27 \%$. Our calculations show that bp composition in Cotoneaster ranges from $58.4 \%$ to $60.8 \%$ AT (Table 3), which agrees with estimates of $59.2 \%$ to $61.1 \%$ AT for three genera from Rosaceae (Meister and Barrow, 2002). We found no relationship between ploidy level (thus genome size) and $\mathrm{AT} \%$, a finding consistent with previous reports in Rosaceae (Meister and Barrow, 2002). Interestingly, we observed a trend that the lower the $\mathrm{AT} \%$, the greater the overestimation of genome size using DAPI compared with PI. 
Table 3. Monoploid (1Cx) genome sizes determined by analysis of nuclei stained with 4',6-diamidino-2-phenylindole (DAPI) or propidium iodide (PI) using Pisum sativum 'Ctirad' $(2 \mathrm{C}=8.76 \mathrm{pg})$ as an internal standard, the difference between genome size estimates between fluorochromes and bp composition of 17 taxa of Cotoneaster.

\begin{tabular}{|c|c|c|c|c|c|c|c|}
\hline Taxa & Accession & Ploidy & $1 \mathrm{Cx}(\mathrm{pg}) \mathrm{DAPI}$ & $1 \mathrm{Cx}(\mathrm{pg}) \mathrm{PI}$ & $P$ value $^{\mathrm{z}}$ & DAPI - PI & $\overline{\mathrm{AT}(\%)}$ \\
\hline Cotoneaster $\times$ suecicus 'Coral Beauty' & $10-0166$ & 2 & 0.77 & 0.74 & 0.096 & 0.03 & 60.8 \\
\hline Cotoneaster applanatus & $09-0067$ & 4 & 0.76 & 0.68 & 0.021 & 0.08 & 59.7 \\
\hline Cotoneaster bacillaris & 09-0073 & 3 & 0.80 & 0.69 & 0.004 & 0.11 & 58.9 \\
\hline Cotoneaster boisianus & 09-0074 & 4 & 0.82 & 0.68 & $<0.001$ & 0.14 & 58.4 \\
\hline Cotoneaster canescens & 09-0079 & 4 & 0.77 & 0.64 & $<0.001$ & 0.13 & 58.4 \\
\hline Cotoneaster cochleatus & 09-0085 & 4 & 0.75 & 0.69 & 0.018 & 0.07 & 59.9 \\
\hline Cotoneaster frigidus & 09-0045 & 2 & 0.76 & 0.70 & 0.032 & 0.06 & 60.1 \\
\hline Cotoneaster milkedandaensis & $10-0174$ & 4 & 0.84 & 0.74 & 0.011 & 0.10 & 59.3 \\
\hline Cotoneaster roseus & $10-0015$ & 4 & 0.75 & 0.70 & 0.049 & 0.05 & 60.2 \\
\hline Cotoneaster sikagensis & $10-0095$ & 4 & 0.80 & 0.70 & 0.002 & 0.11 & 59.0 \\
\hline
\end{tabular}

${ }^{\mathrm{z}} 1 \mathrm{Cx}$ genome size estimates within taxon were compared between fluorochromes using a paired $t$ test $(\alpha=0.05)$.

Even though Parris et al. (2010) found that DAPI underestimated genome size for Magnolia, both of our studies show the same trend: increasing AT\% results in a lower DAPI estimate compared with PI. Although the trends were similar, we observed overestimation using DAPI, whereas Parris et al. (2010) observed underestimation, even though AT\% was similar, albeit higher in their study. A possible source of variation in our study was using different types of tissue in our samples (young stems and vegetative buds) and pea standard (young, expanded leaves). It is possible this resulted in variation in chromatin structure, which would affect the amount of unstainable DNA (Doležel et al., 1992).

Although our choice of fluorochrome influenced genome size estimates, most differences were not large enough to affect ploidy estimation. However, there could be some confusion for several species included in our analysis. For instance, Cotoneaster boisianus showed a $0.14 \mathrm{pg}$ difference in monoploid genome size estimate between fluorochromes. Using the estimate from PI of 2.72, the inferred ploidy level would calculate as $3.5 x$. Without additional information provided from cytological analysis, accurate ploidy assignment may be challenging and sample readings could erroneously be interpreted as aneuploid. DAPI is less expensive, uses less toxic compounds, and often resulted in lower $\mathrm{CV}$ for mean nuclei fluorescence than PI for Cotoneaster. Overall, we consider DAPI acceptable for our purposes in an applied breeding program.

From our chromosome counts in seven species, we found one diploid accession and six tetraploid accessions $(4 x \mathrm{Co}-$ toneaster vandelarii not shown; Fig. 1). These ploidy estimates matched our results from flow cytometry for the five species that were examined by both methods. Overall, when our results were compared with literature for both cytology and flow cytometry, most were in agreement. Where there is conflict in the reports, the conflict may be from the way that the ploidy reports have been generated. Sax (1954) conducted estimations via chromosome counting in pollen mother cells and Zeilinga (1964) found several conflicting reports when root tips were examined. Zeilinga suggested that with polyploids, the chromosome pairing observed in pollen mother cells was crowded and led to confusion in counting. With a relatively high base chromosome number and common occurrence of polyploidy (102 chromosomes in hexaploids), it is possible that previous chromosome counts included errors. Determining ploidy level by counting chromosomes in Cotoneaster was time consuming and difficult, while flow cytometry proved to be much faster and accurate.

Thus far, taxonomic organization in Cotoneaster has largely failed to incorporate molecular data and has relied on morphology and species provenance, although a report by Bartish et al. (2001) using randomly amplified polymorphic DNA supported the recognition of subgenera. Because of the number of species within the genus and the difficulty in organizing Cotoneaster, we hope fundamental information on genome size, ploidy level, and bp composition may give others insight to the relationship among the species. However, the results of this study do not show a relationship of chromosome size to current taxonomic organization, as monoploid genome sizes did not appear to be linked to taxonomic division.

This work may be useful to breeders for predicting success of interspecific hybridization and fertility of $F_{1}$ populations. Along with other factors, similarity in chromosome size contributes to functional meiosis and bivalent pairing between genomes. In this study, monoploid genome sizes varied up to $23 \%$ among species. In Rudbeckia, a hybrid was recovered when there was a difference in genome size of $>300 \%$ (Palmer et al., 2009). The much smaller range in Cotoneaster suggests variation in monoploid genome size, thus chromosome size, is not expected to hinder interspecific hybridization. Furthermore, we have successfully performed several intersubgeneric and interploidy crosses including Cotoneaster $\times$ suecicus 'Coral Beauty' $(2 x, 2 \mathrm{C}=1.53 \mathrm{pg}$, subgenus Chaenopetalum $) \times$ Cotoneaster splendens $(4 x, 2 \mathrm{C}=3.03 \mathrm{pg}$, subgenus Cotoneaster) that resulted in a triploid hybrid, which was confirmed using flow cytometry $(2 \mathrm{C}=2.42 \mathrm{pg})$, thus supporting broad compatibility in the genus. Breeding programs should conduct ploidy analysis for each accession included in a germplasm 

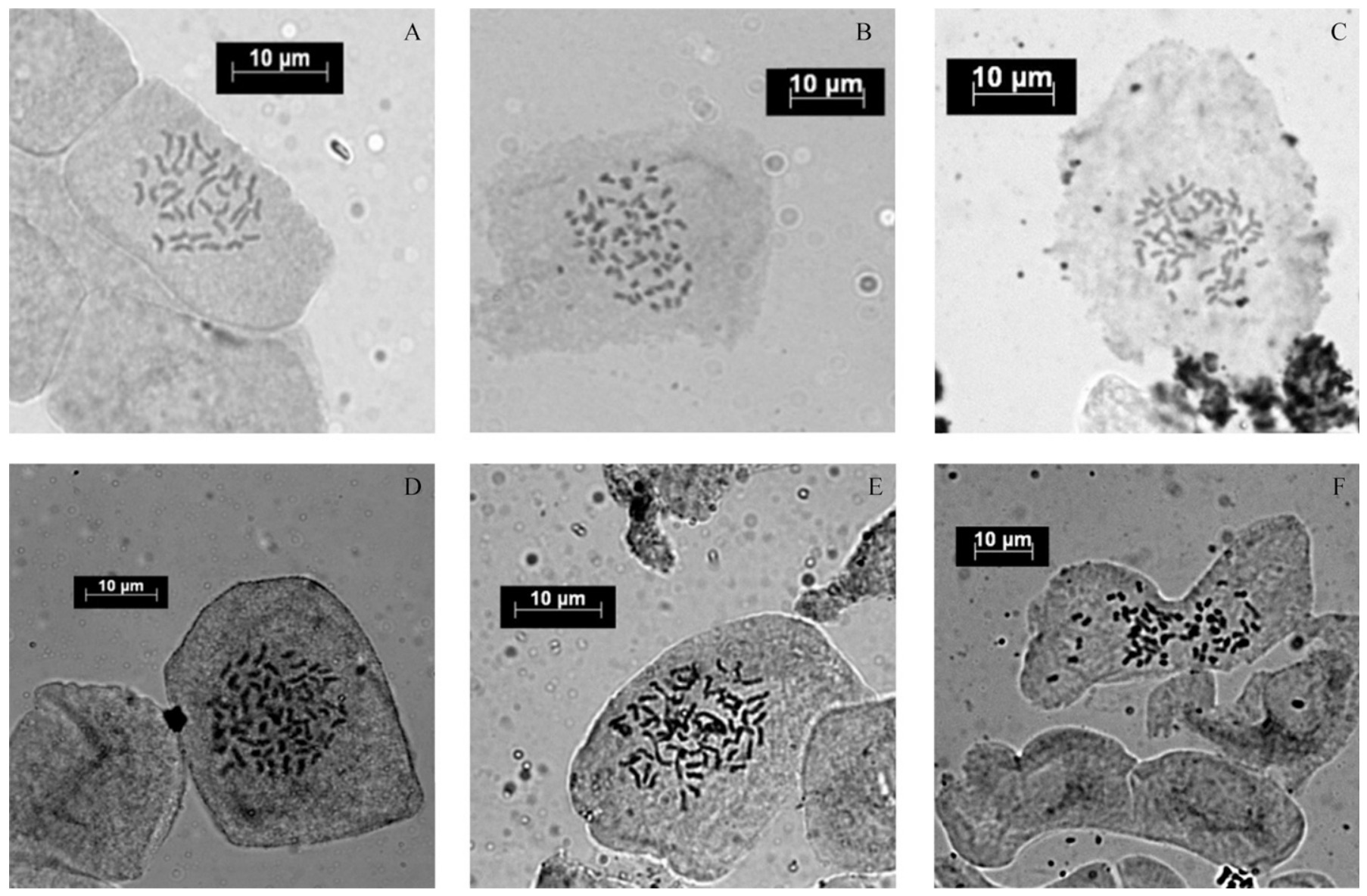

Fig. 1. Photomicrographs of six Cotoneaster accessions including $(\mathbf{A})$ a diploid $(2 n=2 x=34)$ Cotoneaster henryanus, and (B) five tetraploids $(2 n=4 x=68)$ Cotoneaster buxifolius, (C) Cotoneaster vandelarii, (D) Cotoneaster hebephyllus, (E) Cotoneaster lidjiangensis, and (F) Cotoneaster poluninii. Cells were prepared from root tips and chromosomes were stained using modified carbol fuchsin.

collection without relying on previous reports. We expect the broader the survey among species from various sources, the more examples of ploidy series will be found. Nevertheless, we have demonstrated the utility of apomictic polyploids for breeding when used as pollen parents.

Taxonomy of Cotoneaster is challenging due to morphological similarities, the propensity for hybridization, and the presence of apomixis. The tangled issue of separating and correctly identifying these species is emphasized by Dirr (2009) who stated, "Cotoneaster identification is not easy with 400 species, many possibly the result of hybridization, subsequent apomixis, which leads to microspecies that essentially reproduce vegetatively via seed." Our study relied heavily on material obtained through Index Seminum and here we present the material labeled as we received it. Because of the presence of apomixis, particularly among tetraploids, we have strong confidence in the identification of most species presented. It is worth noting that materials in our study were not wild collected as one may expect in a classical floristic study but our findings should be quite relevant to applied plant breeders or others studying cultivated material of Cotoneaster or Maloideae.

\section{Literature Cited}

Bartish, I.V., B. Hylmö, and H. Nybom. 2001. RAPD analysis of interspecific relationships in presumably apomictic Cotoneaster species. Euphytica 120:273-280.
Czapik, R. 1996. Problems of apomictic reproduction in the families Compositae and Rosaceae. Folia Geobot. Phytotaxon. 31:381-387.

Darlington, C.D. and A.P. Wylie. 1956. Chromosome atlas of flowering plants. Macmillan, New York, NY.

Dickson, E.E., K. Arumunganathan, S. Kresovich, and J.J. Doyle. 1992. Nuclear DNA content variation within the Rosaceae. Amer. J. Bot. 79:1081-1086.

Dirr, M.A. 2009. Manual of woody landscape plants. 6th ed. Stipes Publ., Champaign, IL.

Doležel, J., S. Sgorbati, and S. Lucretti. 1992. Comparison of three DNA fluorochromes for flow cytometric estimation of nuclear DNA contents in plants. Physiol. Plant. 85:625-631.

Flinck, K.E. and B. Hylmö. 1966. A list of series and species in the genus Cotoneaster. Bot. Not. 119:445-463.

Fryer, J. and B. Hylmö. 2009. Cotoneasters: A comprehensive guide to shrubs for flowers, fruit and foliage. Timber Press, Portland, OR.

Godelle, B., D. Cartier, D. Marie, S.C. Brown, and S. Siljak-Yakovlev. 1993. Heterochromatin study demonstrating the non-linearity of fluorometry useful for calculating genomic base composition. Cytometry 14:618-626.

Goldblatt, P. and A.H. Gentry. 1979. Cytology of Bignoniaceae. Bot. Not. 132:475-482.

Greilhuber, J., E.M. Temsch, and J.C.M. Loureiro. 2007. Nuclear DNA content measurement, p. 67-101. In: J. Doležel, J. Greilhuber, and J. Suda (eds.). Flow cytometry with plant cells: Analysis of genes, chromosomes and genomes. Wiley-VCH, Weinheim, Germany.

Hjelmqvist, H. 1962. Embryo sac development of Cotoneaster. Bot. Not. 14:209-236. 
Jedrzejczyk, I. and E. Sliwinska. 2010. Leaves and seeds as materials for flow cytometric estimation of the genome size of 11 Rosaceae woody species containing DNA-staining inhibitors. J. Bot. 2010:1-9.

Kroon, G.H. 1975. Polyploidy in Cotoneaster II. Acta Botanisker Neerlandica 24:417-420.

Meister, A. and M. Barrow. 2002. Lack of correlation between AT frequency and genome size in higher plants and the effect of nonrandomness of base sequences on dye binding. Cytometry 47:1-7.

Meister, A. and M. Barrow. 2007. Analysis of genes, chromosomes and genomes, DNA base composition of plant genomes, p. 177-185. In: J. Doležel, J. Greilhuber, and J. Suda (eds.). Flow cytometry with plant cells: Analysis of genes, chromosomes and genomes. Wiley$\mathrm{VCH}$, Weinheim, Germany.

Nybom, H. and I.V. Bartish. 2007. DNA markers and morphometry reveal multiclonal and poorly defined taxa in an apomictic $\mathrm{Co}$ toneaster species complex. Taxon 56:119-128.
Palmer, I.E., T.G. Ranney, N.P. Lynch, and R.E. Bir. 2009. Crossability, cytogenetics and reproductive pathways in Rudbeckia subgenus Rudbeckia. HortScience 44:44-48.

Parris, K.A., T.G. Ranney, H.T. Knap, and W.V. Baird. 2010. Ploidy levels, relative genome sizes, and base pair composition in magnolia. J. Amer. Soc. Hort. Sci. 135:533-547.

Robertson, K.R., J.R. Rohrer, J.B. Phipps, and P.G. Smith. 1991. A synopsis of genera in the subfamily Maloideae (Rosaceae). Syst. Bot. 16:376-394.

Rohrer, J.R., K.R. Robertson, and J.B. Phipps. 1992. Variation in structure among fruits of Maloideae (Rosaceae). Amer. J. Bot. 78:1617-1635.

Sax, H.J. 1954. Polyploidy and apomixis in Cotoneaster. J. Arnold Arbor. 35:334-365.

U.S. Department of Agriculture. 2014. Census of horticultural specialties (2014), Table 19: Broadleaf evergreens, Dec. 2015. 15 Mar. 2016. <http://www.agcensus.usda.gov/Publications/2012/Online_ Resources/Census_of_Horticulture_Specialties/HORTIC.pdf $>$.

Zeilinga, A.E. 1964. Polyploidy in Cotoneaster. Bot. Not. 117:262-278. 